\title{
Effectiveness of Non-Financial Motivation Programs in Domestic and Multinational Pharmaceutical Companies
}

\author{
Md. Mahabub Sharfaraj
}

\begin{abstract}
If the employees of the organization get what they expect from the job, try to do their work with their highest ability. Here in the present study "EFFECTIVENESS OF NON-FINANCIAL MOTIVATION PROGRAMS IN DOMESTIC AND MULTINATIONAL PHARMACEUTICAL COMPANIES" the researcher has presented a comparative measurement of non-financial elements that motivates employees. This is a study on pharmaceutical employees in Bangladesh. We know that every behavior of human being is motivated. To get the best possible service from the employees, there is no alternative way to motivate them. It would be very useful to know that what kind of motivational programs may stimulate them to work. Beside financial motivators, nonfinancial motivators are equally important for motivating employees. Here the researcher has attempted to determine the level of motivation of the employees to the various non-financial motivators existing in their organization. Thus he has tried to know, whether the employees of the selected companies are motivated or not. To measure the motivation level, Likert's five-point scale has been used. The total number and percentage of respondents belonging to each level of satisfaction have been shown separately.

Keywords: Company, Domestic, Motivation, Multinational, Pharmaceutical
\end{abstract}

\section{Introduction}

In the present study, the researcher has looked into the effectiveness of existing non-financial motivational programs of domestic and multinational Pharmaceutical companies in Bangladesh. The researcher has also tried to evaluate the contribution of non-financial motivators to the productivity. In the study a comparative picture of non-financial motivating elements has been presented.

To increase organizational productivity and employee performance, there are several motivational techniques that management can use. "Providing employees with information about the work they have done is important to future productivity efforts, because workers seem to be better motivated as a result [1]." Management must realize that good job performance must be noticed and recognized if it is to continue and poor performance must be corrected if it is going to change [2]. Motivation can also be provided by allowing employees to participate in the goal setting activities. Goals must be conceivable, believable, controllable, measurable and desirable [3]. Allowing employees to have some say in regards to the work methods is also one way a manager can communicate the belief and trust that the employees are responsible. Workers respond best when they are given broader responsibilities, encourage contributing and helped to take satisfaction in their work [4]. Non verbal communication can also motivate individuals. Managers can show interest in employees and what they are doing through expressions of the face or the use of the eyes [5]. As the expression goes, "it is written all over his face." Mangers can also use intrinsic and extrinsic motivators to increase employee's performance and productivity. Intrinsic motivators, such as clean restroom or a nice cafeteria or break room, benefit the employees while on the job [6]. Delegation, job rotation, job enrichment and good listening by manager are also good motivational techniques [7].

We know that all human behavior is motivated. To get the best service of the employees, there is no other way to motivate them. It would be very useful to know that what kind of non-financial motivational programs may stimulate them to work sincerely. In Bangladesh a number of studies on employee motivation have been done. But to the best of the research's knowledge no direct study has so far been undertaken on the pharmaceutical industries.

The findings of this study are expected to be of great use to the entrepreneurs, policy makers, students, human right workers, wage commission, International Labor Organization (ILO) and future researchers. This may help in formulating labor policy, industrial policy in future. It is also expected to add new ideas and knowledge to the existing field regarding employee motivation and employee management.

\section{Objectives Of The Study}

The main objectives of this research are as follows-

1. To identify the non-financial motivational programs in domestic and multinational Pharmaceutical companies in Bangladesh.

2. To measure the level of motivation to every non-financial motivational factor of the selected companies. 
3. To present a comparative picture of motivation to the non-financial motivational programs of domestic and multinational pharmaceutical companies in Bangladesh.

\section{Methodology}

Methodology is the procedural framework within which the research is done. It is the systematic and analytical study of the principles that guides scientific investigation. It describes an approach to a problem that can be put into practice in a research process. Methodology can be defined as, "An operational framework within which the facts are placed, so that their meaning may be seen more clearly."[8] Methodology is foundation of any research. The researcher has to specify some methods for collecting data, processing and analyzing.

\subsection{The Study Area}

There are 229 registered Pharmaceutical manufacturing units in Bangladesh. [9] Seven companies (five domestic and two multinational) have been selected for the study. The study has done by surveying 140 employees. 100 employees from five domestic Pharmaceutical companies (20 from each company) and 40 from two multinational companies (20 form each company) are brought under this survey.

\subsection{Source of data}

Primary data has been used in the study. Here the researcher himself has collected the primary data through direct field investigation. The investigation has been made through interview of employees. Respondents are selected on the basis of stratified random technique.

\subsection{Techniques of data analysis}

Collected data has been processed and analyzed by applying statistical package for the social science (SPSS). Computer has been used widely for analyzing data. Correlation, mean values, $\mathrm{T}$ tests, Chi-square test, percentages, ratios have been used wherever, which one is appropriate. To measure the motivation level Likert's five point scale has been used. The scales used are: highly satisfied, satisfied, neutral, dissatisfied and highly dissatisfied. The scores allotted are five, four, three, two, one respectively. The total number and percentage of respondents belonging to each level of satisfaction have been shown separately.

\subsubsection{Likert scale}

A Likert scale measures the extent to which a person agrees or disagrees with the question. The most common scale is 1 to 5 . Often the scale will be $1=$ strongly disagree, $2=$ disagree, $3=$ not sure, $4=$ agree and $5=$ strongly agree.

\subsubsection{SPSS- Statistical Package for the Social Sciences}

The abbreviation SPSS stands for Statistical Package for the Social Sciences. This package of programs is available for both personal and mainframe (or multi user) computers. [10] These programs are being continuously updated and so there are various versions in existence. In this study the researcher has used the SPSS version 7.5.

\subsubsection{Correlation}

The idea of Correlation is one of the most important and basic in the elaboration of bipartite relationship. Unlike chi-square, measures of correlation indicate both the strength and the direction of the relationship between a pair of variables. Two types of measures can be distinguished: measures of linear Correlation using interval variables and measures of rank Correlation using ordinal variables. While these two types of measures of Correlation share some common properties, they also differ in some important aspects which will be examined after the elucidation of measures of linear Correlation. [11]

\subsubsection{Chi-square test}

If we want to compare the observed frequencies of cases with those expected in a variable that has more than two categories, then we use chi-square (pronounced kye square) test rather than a binominal test. If we want to compare the frequency of cases found in one variable in two or more unrelated samples or categories of another variable, we will also use test. [12]

\section{Definition Of The Key Terms}

The purpose of this research is to evaluate non-financial motivational elements of pharmaceutical industries in Bangladesh. Some terms have been repeatedly used here, which have specific meanings. So this is important to define and discuss the terms/concepts those have been used in this study. 


\subsection{Motivation}

Motivation is the mental force, which makes an individual willing to carry out his duties and responsibilities for the achievement of the goals of his organization. Motivation is the work manager to inspire, encourage and impel people to take required action. [13] Motivation is the cause of human behavior. It may be stated as the key to unlock the power of a person, which already exists in him.

\subsection{Multinational Company}

Multinational Company means a company that has been operating in Bangladesh but its origin may be in any country other than Bangladesh.

\subsection{Domestic Company}

Domestic Company (DC) means an organization whose origin is in Bangladesh. Such a company is controlled and registered under the Bangladesh company law 1994. Here the term domestic company has been used for Bangladeshi public or private limited company or any other company formed and operated abiding Bangladesh government rules and orders.

\section{Effectiveness Of Non-Financial Motivation Programs In Domestic And Multinational Pharmaceutical Companies}

In this paper the researcher has presented a comparative measurement of non-financial elements that motivates employees. The study on motivation has to determine two major things. First, the degree of satisfaction of each category as desired by the employees and second, the extent of which such needs are currently being met effectively. These two figures may help in finding out the deficiency, if any in the area of satisfaction. [14] Here the researcher has attempted to determine the level of motivation of the employees to the various non-financial motivators existing in their organization. Thus he has tried to know, whether the employees of the selected companies are motivated or not.

To measure the motivation level, Likert's five-point scale has been used. The scales used are: highly satisfied, satisfied, neural, dissatisfied, and highly dissatisfied. The scores allotted are five, four, three, two and one respectively. The total number and percentage of respondents belonging to each level of satisfaction have been shown separately.

The level of motivation of the employees to each non-financial factor has shown below-

\subsection{Motivation and Comfortable Working Condition:}

The table (table-1) shows that, 29 percent employees of domestic companies are highly satisfied with their existing working condition, when the percentages of highly satisfied employees in Multinational pharmaceutical companies are 70. Sixty seven percent of the employees of domestic companies are satisfied; when 30 percent employees of multinational companies are satisfied. Four percent of the employees of domestic companies are reluctant to clear their satisfaction or dissatisfaction they are neutral, but no employee in multinational companies is neutral. So it is clear that the working conditions in multinational pharmaceutical companies are better than that of domestic pharmaceutical companies. Total tally of highly satisfied employees are 57 percent, satisfied 56.4 percent and neutral 2.9 percent. No employee of Domestic pharmaceutical companies and Multinational pharmaceutical companies is found dissatisfied or highly dissatisfied.

The Chi-square value between comfortable working condition and company types is 20.328 , which is highly significant i.e. there is an association between comfortable working condition types of companies. That is motivation has been changing because of company's type.

Table-1: Percentage distribution of satisfaction level of employees with Working Condition. (Figures in parenthesis are in percentages)

\begin{tabular}{|c|c|c|c|c|c|c|c|}
\hline Type of & \multicolumn{5}{|c|}{ Motivation and Comfortable working condition } & \multirow{2}{*}{\multicolumn{2}{|c|}{$\begin{array}{l}\text { Total } \\
\text { Index }\end{array}$}} \\
\hline Company & $\begin{array}{c}\text { Highly } \\
\text { dissatisfied }\end{array}$ & Dissatisfied & Neutral & Satisfied & $\begin{array}{l}\text { Highly } \\
\text { satisfied }\end{array}$ & & \\
\hline Domestic & $\begin{array}{l}0 \\
(0)\end{array}$ & $\begin{array}{l}0 \\
(0)\end{array}$ & $\begin{array}{l}4 \\
(4)\end{array}$ & $\begin{array}{l}67 \\
(67.0)\end{array}$ & $\begin{array}{l}29 \\
(29.0)\end{array}$ & $\begin{array}{l}100 \\
(100)\end{array}$ & 1.00 \\
\hline Multinational & $\begin{array}{l}0 \\
(0)\end{array}$ & $\begin{array}{l}0 \\
(0)\end{array}$ & $\begin{array}{l}0 \\
(0)\end{array}$ & $\begin{array}{l}12 \\
(30.0)\end{array}$ & $\begin{array}{l}28 \\
(70.0)\end{array}$ & $\begin{array}{l}40 \\
(100)\end{array}$ & 1.00 \\
\hline Total & $\begin{array}{l}0 \\
(0)\end{array}$ & $\begin{array}{l}0 \\
(0)\end{array}$ & $\begin{array}{l}4 \\
(2.9)\end{array}$ & $\begin{array}{l}79 \\
(56.4)\end{array}$ & $\begin{array}{l}57 \\
(40.7)\end{array}$ & $\begin{array}{l}140 \\
(100)\end{array}$ & 1.00 \\
\hline
\end{tabular}




\subsection{Motivation and Job Itself:}

The table (table-2) shows that, 13 percent employees of domestic companies are highly satisfied with their present job, when the percentage of highly satisfied employees in Multinational pharmaceutical companies is 30. Sixty seven percent of the employees of domestic companies are satisfied; when 70 percent employees of multinational companies are satisfied. Twenty percent of the employees of domestic companies are reluctant to clear their satisfaction or dissatisfaction they are neutral, but no employee in multinational companies is neutral. Total tally of highly satisfied employees are 17.9 percent, satisfied 67.9 percent and neutral 14.3 percent. No employee of Domestic pharmaceutical companies and Multinational pharmaceutical companies is found dissatisfied or highly dissatisfied.

The Chi-square value between job and company types is 12.662 , which is highly significant i.e. there is an association between job and types of companies. That is motivation has been changing because of company's type.

Table-2: Percentage distribution of satisfaction level of employees with their Job. (Figures in parenthesis

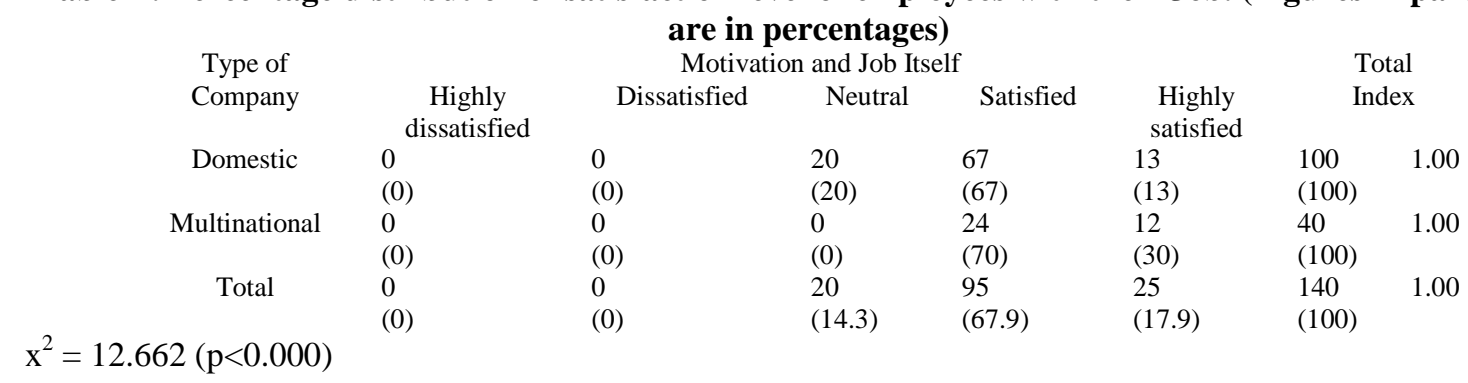

\subsection{Motivation and Appreciation for Good Work Done:}

The table (table-3) shows that, 19 percent employees of domestic companies are highly satisfied with present appreciation for good work, when the percentage of highly satisfied employees in Multinational pharmaceutical companies is 40 . Fifty five percent of the employees of domestic companies are satisfied; when 50 percent employees of multinational companies are satisfied. Twenty six percent of the employees of domestic companies are reluctant to clear their satisfaction or dissatisfaction they are neutral. Total tally of highly satisfied employees are 25 percent, satisfied 63.6 percent and neutral 21.4 percent. No employee of Domestic pharmaceutical companies and Multinational pharmaceutical companies is found dissatisfied or highly dissatisfied.

The Chi-square value between appreciation for good work done and company types is 8.587 , which is highly significant i.e. there is an association between appreciation for good work done and types of companies. That is motivation has been changing because of company's type.

Table-3: Percentage distribution of satisfaction level of employees with Appreciation for good Work done. (Figures in parenthesis are in percentages)

\begin{tabular}{cllllllll} 
Type of & \multicolumn{2}{c}{ Motivation and Appreciation for Good Work Done } & \multicolumn{2}{c}{ Total } \\
Company & $\begin{array}{c}\text { Highly } \\
\text { dissatisfied }\end{array}$ & Dissatisfied & Neutral & Satisfied & Highly & \multicolumn{2}{c}{ Index } \\
& 0 & 0 & 26 & 55 & 19 & 100 & 1.00 \\
Domestic & 0 & $(0)$ & $(0)$ & $(26)$ & $(55)$ & $(19)$ & $(100)$ & \\
& 0 & 0 & 4 & 20 & 16 & 40 & 1.00 \\
Multinational & 0 & $(0)$ & $(10.0)$ & $(50.0)$ & $(40)$ & $(100)$ & \\
& $(0)$ & 0 & 30 & 75 & 35 & 140 & 1.00 \\
Total & 0 & $(0)$ & $(21.4)$ & $(63.6)$ & $(25)$ & $(100)$ &
\end{tabular}

$\mathrm{x}^{2}=8.587(\mathrm{p}<0.014)$

\subsection{Motivation and Good and sympathetic supervision:}

The table (table-4) shows that, 8 percent employees of domestic companies are highly satisfied with supervision, when the percentage of highly satisfied employees in Multinational pharmaceutical companies is 12.5. Fifty five percent of the employees of domestic companies are satisfied; when 60 percent employees of multinational companies are satisfied. Thirty percent of the employees of domestic companies are reluctant to clear their satisfaction or dissatisfaction they are neutral, Twenty percent of employees in multinational companies are neutral. Total tally of highly satisfied employees are 9.3 percent, satisfied 56.4 percent, neutral 2.9 percent and dissatisfied 5 percent. No employee of Domestic pharmaceutical companies and Multinational pharmaceutical companies is highly dissatisfied. 
The Chi-square value between Good and sympathetic supervision and company types is 3.098, which is not significant i.e. there is no association between Good and sympathetic supervision and types of companies.

Table-4: Percentage distribution of satisfaction level of employees with supervision. (Figures in parenthesis are in percentage)

Type of Company

Motivation and Good and sympathetic supervision Dissatisfied Neutral Satisfied

\begin{tabular}{cl} 
& \multicolumn{1}{c}{$\begin{array}{c}\text { Highly } \\
\text { dissatisfied }\end{array}$} \\
Domestic & 0 \\
& $(0)$ \\
Multinational & 0 \\
& $(0)$ \\
Total & 0
\end{tabular}

(0)

4
$(4)$
3
$(7.5)$
7
$(5)$

(5)

$\begin{array}{ll} & \\ 33 & 55 \\ (33) & (55) \\ 8 & 24 \\ (2) & (6.0) \\ 41 & 79 \\ (29.3) & (56.4)\end{array}$

$\begin{gathered}\text { Highly } \\ \text { satisfied }\end{gathered}$
8
$(8)$
5
$(12.5)$
13
$(9.3)$

\begin{tabular}{lr}
\multicolumn{1}{r}{$\begin{array}{c}\text { Total } \\
\text { Index }\end{array}$} \\
\\
100 \\
$(100)$ & .92 \\
40 & \\
$(100)$ & .85 \\
140 & \\
$(100)$ & \\
\hline
\end{tabular}

$\mathrm{x}^{2}=3.098(\mathrm{p}<0.377)$

\subsection{Motivation and Training:}

The table (table-5) shows that, 13 percent employees of domestic companies are highly satisfied with their existing training, when the percentage of highly satisfied employees in Multinational pharmaceutical companies are 25.Fifty nine percent of the employees of domestic companies are satisfied; when 57.5 percent employees of multinational companies are satisfied. 27 percent of the employees of domestic companies are reluctant to clear their satisfaction or dissatisfaction they are neutral, but no employee in multinational companies is neutral. Total tally of highly satisfied employees are 16.4 percent, satisfied 58.6 percent neutral 24.3 percent and dissatisfied .7 percent. No employee of Domestic pharmaceutical companies and Multinational pharmaceutical companies is found highly dissatisfied about their training arrangement.

The Chi-square value between training and company types is 3.977 , which is not significant i.e. there is no association between training and types of companies.

Table-5: Percentage distribution of satisfaction level of employees with Training. (Figures in parenthesis

\begin{tabular}{|c|c|c|c|c|c|c|c|}
\hline \multirow{2}{*}{ Type of Company } & \multicolumn{7}{|c|}{ are in percentages) } \\
\hline & $\begin{array}{c}\text { Highly } \\
\text { dissatisfied }\end{array}$ & Dissatisfied & Neutral & Satisfied & $\begin{array}{l}\text { Highly } \\
\text { satisfied }\end{array}$ & & \\
\hline Domestic & $\begin{array}{l}0 \\
(0)\end{array}$ & $\begin{array}{l}1 \\
(1)\end{array}$ & $\begin{array}{l}27 \\
(27)\end{array}$ & $\begin{array}{l}59 \\
(59)\end{array}$ & $\begin{array}{l}13 \\
(13)\end{array}$ & $\begin{array}{l}100 \\
(100)\end{array}$ & .98 \\
\hline Multinational & $\begin{array}{l}0 \\
(0)\end{array}$ & $\begin{array}{l}0 \\
(0)\end{array}$ & $\begin{array}{l}7 \\
(17.5)\end{array}$ & $\begin{array}{l}23 \\
(57.5)\end{array}$ & $\begin{array}{l}10 \\
(25)\end{array}$ & $\begin{array}{l}40 \\
(100)\end{array}$ & 1.00 \\
\hline Total & $\begin{array}{l}0 \\
(0)\end{array}$ & $\begin{array}{l}1 \\
(.7)\end{array}$ & $\begin{array}{l}34 \\
(24.3)\end{array}$ & $\begin{array}{l}82 \\
(58.4)\end{array}$ & $\begin{array}{l}23 \\
(16.4)\end{array}$ & $\begin{array}{l}140 \\
(100)\end{array}$ & .99 \\
\hline
\end{tabular}

\subsection{Motivation and Job Security and Stability:}

The table (table-6) shows that, 13 percent employees of domestic companies are highly satisfied with their job security, when the percentage of highly satisfied employees in Multinational pharmaceutical companies is 20. Seventy percent of the employees of domestic companies are satisfied; when 67.5 percent employees of multinational companies are satisfied. Fifteen percent of the employees of domestic companies are reluctant to clear their satisfaction or dissatisfaction they are neutral, ten percent employees in multinational companies are neutral. Two percent employees of Domestic pharmaceutical companies and 2.5 percent employees of Multinational pharmaceutical companies are dissatisfied. Total tally of highly satisfied employees are 21 percent, satisfied 69.3 percent, neutral 13.6 percent and dissatisfied 2.1 percent. No employee of Domestic pharmaceutical companies and Multinational pharmaceutical companies is found highly dissatisfied.

The Chi-square value between job security and company types is 1.519 , which is not significant i.e. there is no association between job security and types of companies.

Table-6: Percentage distribution of satisfaction level of employees with job security. (Figures in parenthesis are in percentages)

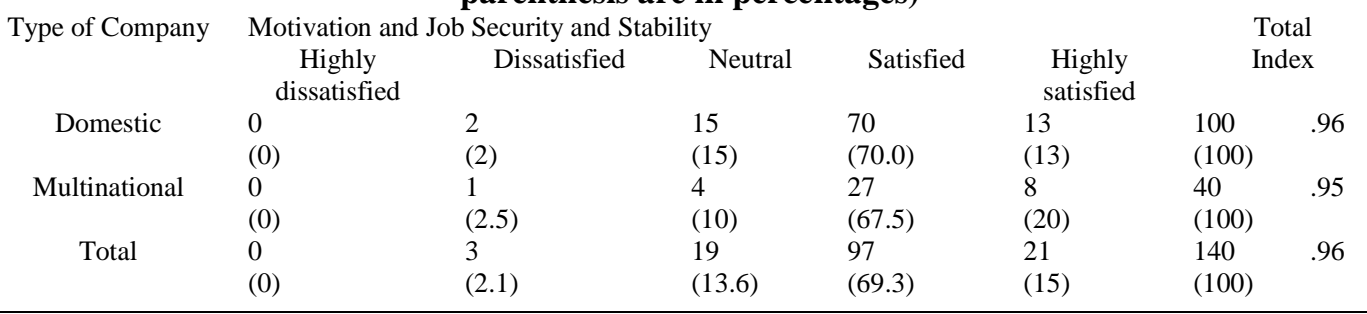


$\mathrm{x}^{2}=1.519(\mathrm{p}<0.678)$

\subsection{Motivation and Sympathy and Help on Personal Matters:}

The table (table-7) shows that, 2 percent employees of domestic companies are highly satisfied with sympathy and help on personal matters, when the percentage of highly satisfied employees in Multinational pharmaceutical companies is 5.28 percent of the employees of domestic companies are satisfied; when 25 percent employees of multinational companies are satisfied. Fifty percent of the employees of domestic companies are reluctant to clear their satisfaction or dissatisfaction they are neutral, 47.5 percent employees of multinational companies are neutral. 19 percent employees of Domestic pharmaceutical companies are dissatisfied, 15 percent of employees of Multinational pharmaceutical companies are dissatisfied. One percent employee of Domestic pharmaceutical companies and 7.5 percent employee of Multinational pharmaceutical companies are highly dissatisfied. Total tally of highly satisfied employees are 2.9 percent, satisfied 27.1 percent, neutral 49.3 percent, dissatisfied 17.9 percent and highly dissatisfied 2.9 percent.

The Chi-square value between sympathy and help on personal matters and company types is 5.512, which is not significant i.e. there is no association between sympathy and help on personal matters and types of companies.

Table-7: Percentage distribution of satisfaction level of employees with sympathy and Help on Personal Matters. (Figures in parenthesis are in percentages)

\begin{tabular}{cllllllll}
$\begin{array}{c}\text { Type of } \\
\text { Company }\end{array}$ & \multicolumn{2}{c}{$\begin{array}{c}\text { Motivation and Sympathy and Help on Personal Matters } \\
\text { Highly } \\
\text { dissatisfied }\end{array}$} & Dissatisfied & Neutral & Satisfied & \multicolumn{2}{c}{$\begin{array}{c}\text { Highly } \\
\text { satisfied }\end{array}$} & \multicolumn{2}{c}{$\begin{array}{c}\text { Total } \\
\text { Index }\end{array}$} \\
Domestic & 1 & 19 & 50 & 28 & 2 & 100 & .60 \\
& $(1)$ & $(19)$ & $(50)$ & $(28)$ & $(2)$ & $(100)$ & \\
Multinational & 3 & 6 & 19 & 10 & 2 & 40 & .55 \\
& $(7.5)$ & $(15)$ & $(47.5)$ & $(25)$ & $(5)$ & $(100)$ & \\
Total & 4 & 25 & 69 & 38 & 4 & 140 & .59 \\
& $(2.9)$ & $(17.9)$ & $(49.3)$ & $(27.1)$ & $(2.9)$ & $(100)$ &
\end{tabular}

$\mathrm{x}^{2}=5.512(\mathrm{p}<0.239)$

(27.1)

(100)

\subsection{Motivation Opportunity for Making Friendship:}

The table (table-8) shows that, One percent employee of domestic companies are highly satisfied with their existing opportunity for making friendship, no employee of Multinational pharmaceutical companies are highly satisfied. 13 percent of the employees of domestic companies are satisfied; when 25 percent employees of multinational companies are satisfied. 55 percent of the employees of domestic companies are reluctant to clear their satisfaction or dissatisfaction they are neutral, 27.5 percent of employees in multinational companies are neutral. Thirty percent employees of Domestic pharmaceutical companies and 45 employees of Multinational pharmaceutical companies are dissatisfied. One percent employee of Domestic pharmaceutical companies and 2.5 percent employees of Multinational pharmaceutical companies are highly dissatisfied. Total .7 percent employees are highly satisfied, satisfied 16.4 percent, neutral 47.1 percent, dissatisfied 34.3 percent and highly dissatisfied 1.4 percent.

The Chi-square value between opportunity for making friendship and company types is 9.813 , which is significant i.e. there is an association between opportunity for making friendship and types of companies. That is motivation has been changing because of company's type.

Table-8: Percentage distribution of satisfaction level of employees with Opportunity for Making Friendship. (Figures in parenthesis are in percentages)

\begin{tabular}{|c|c|c|c|c|c|c|c|}
\hline \multirow[t]{2}{*}{ Type of Company } & & \multicolumn{3}{|c|}{ Motivation Opportunity for Making Friendship } & \multirow{2}{*}{$\begin{array}{c}\text { Highly } \\
\text { satisfied }\end{array}$} & \multicolumn{2}{|c|}{ Total } \\
\hline & $\begin{array}{c}\text { Highly } \\
\text { dissatisfied }\end{array}$ & Dissatisfied & Neutral & Satisfied & & & \\
\hline Domestic & $\begin{array}{l}1 \\
(1)\end{array}$ & $\begin{array}{l}30 \\
(30)\end{array}$ & $\begin{array}{l}55 \\
(55)\end{array}$ & $\begin{array}{l}13 \\
(13)\end{array}$ & $\begin{array}{l}1 \\
(1)\end{array}$ & $\begin{array}{l}100 \\
(100)\end{array}$ & .38 \\
\hline Multinational & $\begin{array}{l}1 \\
(2.5)\end{array}$ & $\begin{array}{l}18 \\
(45)\end{array}$ & $\begin{array}{l}11 \\
(27.5)\end{array}$ & $\begin{array}{l}10 \\
(25)\end{array}$ & $\begin{array}{l}0 \\
(0)\end{array}$ & $\begin{array}{l}40 \\
(100)\end{array}$ & .05 \\
\hline Total & $\begin{array}{l}2 \\
(1.4)\end{array}$ & $\begin{array}{l}48 \\
(34.3)\end{array}$ & $\begin{array}{l}66 \\
(47.1)\end{array}$ & $\begin{array}{l}23 \\
(16.4)\end{array}$ & $\begin{array}{l}1 \\
(.7)\end{array}$ & $\begin{array}{l}140 \\
(100)\end{array}$ & .29 \\
\hline
\end{tabular}

\subsection{Motivation and Opportunity for Creative Thinking and Expression:}

The table (table-9) shows that, One percent employee of domestic companies is highly satisfied with their existing opportunity for creative Thinking and expression, no employee of Multinational pharmaceutical 
companies is highly satisfied. Six percent of the employees of domestic companies are satisfied; when 10 percent employees of multinational companies are satisfied. Thirteen percent of the employees of domestic companies are reluctant to clear their satisfaction or dissatisfaction they are neutral, 15 percent employees of multinational companies are neutral. 51 percent employees of Domestic pharmaceutical companies and 55percent employees of multinational pharmaceutical companies are dissatisfied. Twenty nine percent employees of domestic pharmaceutical companies and 20 percent employees of Multinational pharmaceutical companies are highly dissatisfied. Total .7 percent employees are highly satisfied, satisfied 7.1 percent, neutral 13.6 percent, dissatisfied 52.1 percent and highly dissatisfied 26.4 percent.

The Chi-square value between opportunity for creative thinking and expression and company types is 2.088, which is not significant i.e. there is no association between opportunity for creative thinking and expression and types of companies.

Table-9: Percentage distribution of satisfaction level of employees with Opportunity for creative thinking and expression. (Figures in parenthesis are in percentages)

\begin{tabular}{|c|c|c|c|c|c|c|c|}
\hline \multirow[t]{2}{*}{ Type of Company } & \multicolumn{6}{|c|}{ Motivation and Opportunity for Creative Thinking and Expression } & \multirow{2}{*}{$\begin{array}{l}\text { otal } \\
\text { hdex }\end{array}$} \\
\hline & $\begin{array}{c}\text { Highly } \\
\text { dissatisfied }\end{array}$ & Dissatisfied & Neutral & Satisfied & $\begin{array}{l}\text { Highly } \\
\text { satisfied }\end{array}$ & & \\
\hline Domestic & $\begin{array}{l}29 \\
(29)\end{array}$ & $\begin{array}{l}51 \\
(51)\end{array}$ & $\begin{array}{l}13 \\
(13)\end{array}$ & $\begin{array}{l}6 \\
(6)\end{array}$ & $\begin{array}{l}1 \\
\text { (1) }\end{array}$ & $\begin{array}{l}100 \\
(100)\end{array}$ & -.60 \\
\hline Multinational & $\begin{array}{l}8 \\
(20)\end{array}$ & $\begin{array}{l}22 \\
(55)\end{array}$ & $\begin{array}{l}6 \\
(15)\end{array}$ & $\begin{array}{l}4 \\
(10)\end{array}$ & $\begin{array}{l}0 \\
(0)\end{array}$ & $\begin{array}{l}40 \\
(100)\end{array}$ & -.50 \\
\hline Total & $\begin{array}{l}37 \\
(26.4)\end{array}$ & $\begin{array}{l}73 \\
(52.1)\end{array}$ & $\begin{array}{l}19 \\
(13.6)\end{array}$ & $\begin{array}{l}10 \\
(7.1)\end{array}$ & $\begin{array}{l}1 \\
(.7)\end{array}$ & $\begin{array}{l}140 \\
(100)\end{array}$ & -.57 \\
\hline
\end{tabular}

$\mathrm{x}^{2}=2.088(\mathrm{p}<0.720)$

\subsection{Motivation and Opportunity to Participate in Decision Making:}

The table (table-10) shows that, 7 percent employees of domestic companies are satisfied with their participation in decision making, when the percentages of satisfied employees in Multinational pharmaceutical companies are 2.5. Seven percent of the employees of domestic companies are reluctant to clear their satisfaction or dissatisfaction they are neutral, 12.5 percent employees of multinational companies are neutral. Fifty three percent employees of Domestic pharmaceutical companies and 45 percent employees of Multinational pharmaceutical companies are dissatisfied. Thirty three percent employee of Domestic pharmaceutical companies and 40 percent employees of Multinational pharmaceutical companies are highly dissatisfied. Total satisfied 7.1 percent, neutral 8.6 percent, and dissatisfied 50.7 percent and highly dissatisfied 35 percent. NO employee of Multinational pharmaceutical companies or Domestic pharmaceutical companies is highly satisfied.

The Chi-square value between opportunity to participate in decision making and company types is 2.781, which is not significant i.e. there is no association between participation in decision making and types of companies.

Table-10: Percentage distribution of satisfaction level of employees with Opportunity to Participate in Decision Making. (Figures in parenthesis are in percentages)

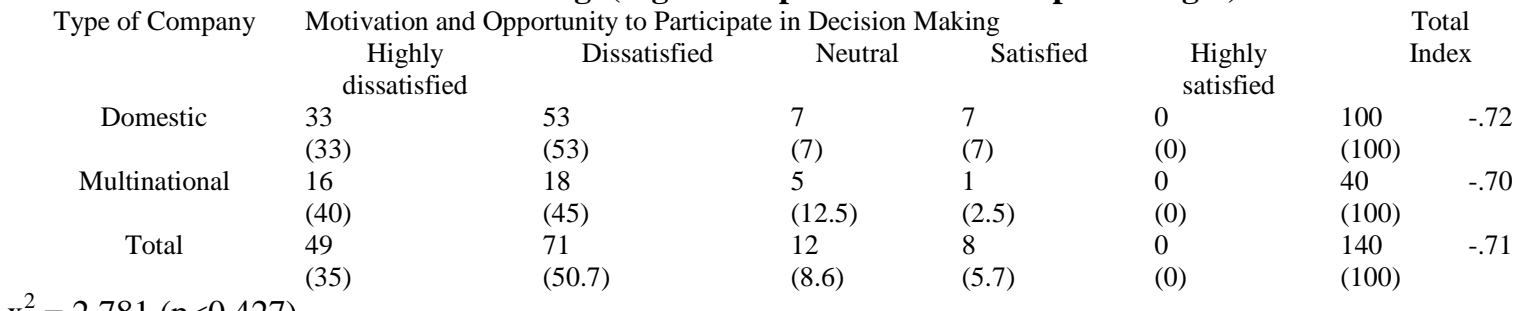

\subsection{Motivation and Opportunity to Exercise Power and Authority:}

The table (table-11) shows that, 8 percent employees of domestic companies are satisfied with opportunity to exercise power and authority, the percentage of satisfied employees in Multinational pharmaceutical companies are 12.5 Eight percent of the employees of domestic companies are reluctant to clear their satisfaction or dissatisfaction they are neutral, 10 percent employees of multinational companies are neutral. Forty three percent employees of Domestic pharmaceutical companies and 42.5 percent employees of Multinational pharmaceutical companies are dissatisfied. Forty one percent employee of Domestic pharmaceutical companies and 35 percent employees of Multinational pharmaceutical companies are highly dissatisfied. Total satisfied 9.3 percent, neutral 8.6 percent, dissatisfied 42.9 and highly dissatisfied 39.3 percent. 
NO employee of Multinational pharmaceutical companies or Domestic pharmaceutical companies is highly satisfied.

The Chi-square value between opportunity to exercise power and authority and company type is 1.020 , which is not significant i.e. there is no association between opportunity to exercise power and authority and types of companies.

Table-11: Percentage distribution of satisfaction level of employees with Opportunity to exercise power

Type of Company
Domestic
Multinational
Total

$\mathrm{x}^{2}=1.020(\mathrm{p}<0.796)$ and authority. (Figures in parenthesis are in percentages)

\begin{tabular}{|c|c|c|c|c|c|c|}
\hline \multicolumn{6}{|c|}{ Motivation and Opportunity to Exercise Power and Authority } & \multirow{2}{*}{$\begin{array}{l}\text { Total } \\
\text { Index }\end{array}$} \\
\hline Highly dissatisfied & Dissatisfied & Neutral & Satisfied & $\begin{array}{l}\text { Highly } \\
\text { satisfied }\end{array}$ & & \\
\hline 41 & 43 & 8 & 8 & 0 & 100 & -.68 \\
\hline (41) & (43) & (8) & (8) & (0) & (100) & \\
\hline 14 & 17 & 4 & 5 & 0 & 40 & -.55 \\
\hline (35) & $(42.5)$ & (10) & (12.5) & (0) & (100) & \\
\hline 55 & 60 & 12 & 13 & 0 & 140 & -.64 \\
\hline (39.3) & (42.9) & (8.6) & (9.3) & (0) & (100) & \\
\hline
\end{tabular}

\subsection{Right Man in the Right Post:}

Table (table-12) shows that, Seven percent employees of domestic companies are highly satisfied to be posted right man in the right post, when the percentage of highly satisfied employees in Multinational pharmaceutical companies are 7.5. Sixty six percent of the employees of domestic companies are satisfied; when 75 percent employees of multinational companies are satisfied. Twenty three percent of the employees of domestic companies are reluctant to clear their satisfaction or dissatisfaction they are neutral, 12.5 percent employee of multinational companies are neutral. 4 percent employees of domestic pharmaceutical companies are dissatisfied, but no employee of multinational pharmaceutical companies is dissatisfied. Total tally of highly satisfied employees are 7.1 percent, satisfied 68.6 percent and neutral 20 percent, dissatisfied 2.9 percent and highly dissatisfied 1.4 percent.

The Chi-square value between right posting of man and company types is 8.523 , which is not significant i.e. there is no association between right posting of man and types of companies.

Table-12: Percentage distribution of satisfaction level of employees with Right Posting. (Figures in parenthesis are in percentages)

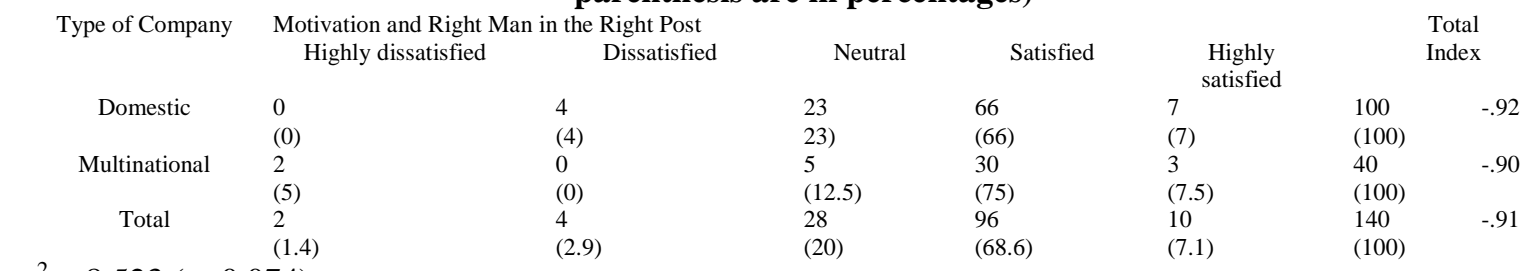

$\mathrm{x}^{2}=8.523(\mathrm{p}<0.074)$

\subsection{Goodwill of the Organization:}

The table (table-13) shows that, 63 percent employees of domestic companies are highly satisfied with goodwill of the organization, when the percentage of highly satisfied employees in multinational pharmaceutical companies is 70 . Thirty one percent of the employees of domestic companies are satisfied; when 17.5 percent employees of multinational companies are satisfied. Six percent of the employees of domestic companies are reluctant to clear their satisfaction or dissatisfaction they are neutral, 12.5 percent of employees in multinational companies are neutral. Total tally of highly satisfied employees are 65 percent, satisfied 27.1 percent and neutral 7.9 percent. No employee of Domestic pharmaceutical companies and Multinational pharmaceutical companies is found dissatisfied or highly dissatisfied.

The Chi-square value between goodwill of the organization and company types is 3.670 , which is not significant i.e. there is no association between Goodwill of the organization and types of companies.

Table-13: Percentage distribution of satisfaction level of employee with Goodwill of the organization.

\begin{tabular}{cl} 
Type of Company & \\
& \multicolumn{1}{c}{ Highly dissatisfied } \\
Domestic & 0 \\
& $(0)$ \\
Multinational & 0 \\
Total & $(0)$ \\
& 0 \\
$\mathrm{X}^{2}=3.670(\mathrm{p}<0.160-\mathrm{NS})$
\end{tabular}

(Figures in parenthesis are in percentages)

\begin{tabular}{llllll}
\multicolumn{2}{c}{$\begin{array}{c}\text { Goodwill of the Organization } \\
\text { Dissatisfied }\end{array}$} & \multicolumn{2}{c}{ Neutral } & Satisfied & \multicolumn{2}{c}{$\begin{array}{c}\text { Hotal } \\
\text { Highly }\end{array}$} & \multicolumn{2}{c}{ Index } \\
0 & 6 & 31 & 63 & 100 & 1.00 \\
$(0)$ & $(6)$ & $(31)$ & $(63)$ & $(100)$ & \\
0 & 5 & 7 & 28 & 40 & 1.00 \\
$(0)$ & $(12.5)$ & $(17.5)$ & $(70)$ & $(100)$ & \\
0 & 11 & 38 & 91 & 140 & 1.00 \\
$(0)$ & $(7.9)$ & $(27.1)$ & $(65)$ & $(100)$ &
\end{tabular}




\section{Conclusion}

The presence of non-financial employee motivating elements in pharmaceutical companies is satisfactory. Employee motivation is a consistence process. So the management should be always vigilant about the employee's unfulfilled demands. Some non-financial programs need to be further developed. Non-financial motivational elements like sympathy and help on personal matters, opportunity for making friendship, opportunity for creative thinking and expression, opportunity to participate in decision making, opportunity to exercise power and authority need to be given more cordial attention..

Despite the best effort of the researcher, the present study is not above some limitations. The sample size might not satisfactory. Here only seven companies from two categories have been brought under investigation. All employees of these seven companies were not investigated. One hundred and forty employees were interviewed. This is difficult to ensure that the numbers of the employees have reflected the picture of the whole sector. The research has been done on the Bangladesh perspective. Unemployment is the main problem in the society. So a person who can manage a job tries heart and soul to secure it. All motivational factors are not equally important to the employees. Pharmaceutical is a manufacturing industry. But this cannot be assured that the motivation programs of this industry will be equally applicable for others manufacturing industries in Bangladesh.

\section{References}

[1] Stephen E. Catt, and Donald S. Miller, Human Relations: Contemporary Approach (Illinois: Richard D. Irwin Inc., 1989). 86.

[2] Norman C. Hill, Increasing Management Effectiveness: Keys to Management and Motivation (Calif: Addision-Wesley Publishing, 1979). 94

[3] Stephen E. Catt, and Donald S. Miller, Human Relations: Contemporary Approach (Illinois: Richard D. Irwin Inc., 1989). 87.

[4] Stephen E. Catt, and Donald S. Miller, Human Relations: Contemporary Approach (Illinois: Richard D. Irwin Inc., 1989). 13.

[5] Norman C. Hill, Increasing Management Effectiveness: Keys to Management and Motivation (Calif: Addision-Wesley Publishing, 1979). 89.

[6] T.J. McCoy, Compensation and Motivation (American Management Association, NY, 1992).136.

[7] J.L. Frunzi and P.E. Savini, Supervision : The Art of Management(New Jersey: Prentice Hall Inc, 1997). 160.

[8] Den Remenyyi, et al., Doing Research in Business and Management (London: SAGE Publications, 1998\}. 28

[9] Sarwar Zahan, Pharmaceutical: A Sector That is Delivering. Business Bangladesh, $1^{\text {st }}$ march, 2004, p. 22

[10] A. Bryman and D. Cramer, Quantitative data analysis with SPSS for windows (New York: Routledge, 1997). 16.

[11] A. Bryman and D. Cramer, Quantitative data analysis with SPSS for windows (New York: Routledge, 1997$) .172$.

[12] Alan Bryman and Duncan Cramer, Quantitative data analysis with SPSS for windows (New York: Routledge,1997). 121-124.

[13] Norman c. Hill, Increasing managerial Effectiveness: Keys to Management and Motivation (Calif, Addision - Wesley Publishing, 1979). 85.

[14] Mohammod Nurul Islam, Effectiveness of Motivation Programs of public Sector Banking in Bangladesh: A Study of Janata Bank, Unpublished Ph.D thesis, Rajshahi: IBS, 1997, 138. 